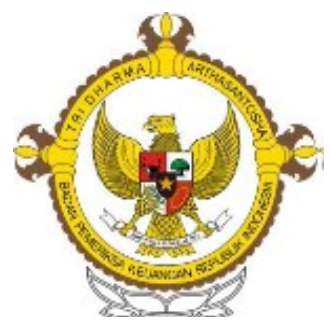

JURNAL
TATA KELOLA \& AKUNTABILITAS K
e-ISSN 2549-452X
p-ISSN 2460-3937

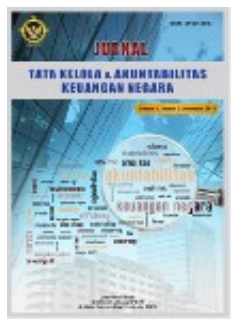

\title{
ELEMENTS WHICH TRIGGER EMPLOYEE'S INTENTION TO DISCLOSE FRAUD VIA A WHISTLEBLOWING SYSTEM: A CASE STUDY
}

\author{
Putri Anggraini $^{1}$ and Ramadhan Nugraha Putra ${ }^{2}$ \\ Badan Pemeriksa Keuangan Republik Indonesia \\ putri.anggraini@bpk.go.id ${ }^{1}$ \\ ramadhan.putra@bpk.go.id ${ }^{2}$
}

\begin{abstract}
Fraud is very liquid; thus, it could occur both in public sector and private institutions. The consequences of fraud could be very damaging such as the loss of assets and the ruin of a company's reputation. BPK as one of the governmental institutions in Indonesia is obliged to implement a whistleblowing system as a means to detect any fraudulent activities. It is believed that an effective whistleblowing system is likely to be credible and secure so that all employees could disclose misconducts without any hesitation. Therefore, this study aims to contribute to the novelty of the whistleblowing system which has been implemented in BPK. There are several elements to be considered in setting up a whistleblowing system namely, secrecy of the tipsters' identity, incentives, whistleblowers' protection, accessibility, training of ethical program, power owned by the addressee, the perpetrators and the potential whistleblowers, management's support as well as their response to the tips given by the employees. A questionnaire and descriptive statistical analysis are used to rank the elements from the most important to the least essential items in a whistleblowing system from the perspective of the employees in BPK. The result shows that BPK's employees consider the whistleblowers' protection as the most critical element in the system; whereas, rewards is the least factor which triggers them to blow the whistle. Those elements, however, are integral parts which complement each other in establishing an effective whistleblowing mechanism.
\end{abstract}

\section{KEYWORDS:}

whistleblowing; fraud; employee's intention

\section{ARTICLE HISTORY:}




\section{INTRODUCTION}

The saying of "no one would win when fraud occurs" is a reality. Both a fraud perpetrator and an organization are likely to tackle adverse consequences of the fraudulent activities (Albrecht et al., 2014; Lowe et al., 2015). When most organizations would suffer a significant loss as a result of stolen assets, expensive investigation process and reputation damage, the wrongdoers would have to face an embarrassment towards society and a loss of public trust. Unfortunately, fraudulent behaviour among employees, managers and the company's third parties is extensive and needs to be rigorously curtailed. This is shown by the fact that the total number of fraud cases increase year by year (ACFE, 2016; Albrecht et al., 2014; KPMG, 2012; Lee \& Fargher, 2013).

Some say that it is the auditors' responsibility to detect fraud in a client's organization. Nevertheless, Albrecht et al. (2014) claim that auditors are rarely present when the funds are stolen, bribery is conducted, or fraud is committed. The authors argue that it would be hard for them to detect fraud when the fraudsters commit and conceal the fraud as well as convert the stolen assets. It is probably because of the nature of the auditors' work-cycle, for instance, they would just spend a few weeks working in the organization during an audit period, but they would stop as the audit period ends. Furthermore, auditors would not recognise the perpetrators' unusual behaviour, such as driving luxurious cars or living an extravagant lifestyle. Therefore, it is usually co-workers, managers and other employees who are in the best position to detect fraud in the first place (Albrecht et al., 2014; Apaza \& Chang, 2011; Dasgupta \& Kesharwani, 2010; Lewis \& Trygstad, 2009; Lowe et al., 2015). Consequently, managers of the organizations need to formulate a sufficient mechanism to detect fraud as early as possible before the amount of loss becomes too material.

This awareness highlights the necessity of receiving tips and complaints from staff and managers when they have a knowledge or a suspicion that fraud is happening in the organization (Albrecht et al., 2014; Lowe et al., 2015). Besides, Pittroff (2014) believes that the invaluable information given by the other employees would prevent a huge detriment in the organization. Therefore, most governmental institutions across the world established mandatory obligations for public organizations as well as private institutions to implement a whistleblowing system. Pittroff (2014) also argues that a whistleblowing system is a crucial tool in the process of successful fraud detection in both private and public sector organizations.

\section{Key Elements of a Whistleblowing System}

A whistleblowing system is a means to accommodate the tips and complaints which are made by current or former workers of an institution as well as to bring the perpetrators to the light (Apaza \& Chang, 2011; Dasgupta \& Kesharwani, 2010). The authors claim that employees would disclose some red flags to a person or an organization that could follow up their tips optimally (or an addressee). The mechanism, however, may have some challenges to overcome such as the employees' hesitancy due to possible retaliation or they may distrust the addressee (Lee \& Fargher, 2013). These issues could indirectly cause the whistleblowing system to fail.

There are some factors to be considered that would trigger and/or weaken employees' intention to utilise a whistleblowing system, such as (1) power to influence the participants who are potential whistleblowers and the addressee (Pittroff, 2014), (2) power of 
the suspected wrongdoers (Gao et al., 2014; Pittroff, 2014; Robinson et al., 2012), (3) anonymity and confidentiality (Albrecht et al., 2014; Alleyne et al., 2017; Lee \& Fargher, 2013; Pittroff, 2014), (4) incentives or rewards (Alleyne et al., 2017; Dasgupta \& Kesharwani, 2010; Rose, et al., 2018; Yeoh, 2014), (5) tipsters' protection (Apaza \& Chang, 2011; Lewis \& Trygstad, 2009; Parker, et al., 2017; Pittroff, 2014), (6) management's support (Alleyne et al., 2017; Kastiel, 2015; Lee \& Fargher, 2013), (7) accessibility (Kastiel, 2015; Lee \& Fargher, 2013), (8) training of ethical programs (Alleyne et al., 2017; Robinson et al., 2012), as well as (9) action or follow up from the addressee (Lee \& Fargher, 2013; Lowe et al., 2015).

To our best knowledge, no prior studies have evaluated those elements altogether as an integral factor in setting up the system. Thus, to distinguish this study from the previous ones, the authors will, firstly, examine the elements simultaneously. Secondly, while most of the studies related to whistleblowing were conducted in developed countries, the authors will focus on a developing country which is Indonesia (World Bank, 2017). Indonesia is chosen because as a developing country, Indonesia is struggling to eradicate fraudulent activities among employees and managers who sit in a high or low managerial level, both in public and private sectors. Based on the Association of Certified Fraud Examiners or ACFE's report (2016), Indonesia has the second highest number of fraud cases among countries in the Asia-Pacific region with 42 cases, just below China with 64 occurrences. Indonesia, additionally, was ranked 96 out of the 180 countries with the highest number of corruption cases (Transparency International, 2017). Lastly, many studies related to the implementation of whistleblowing are concentrated on private companies; then, this study will focus on the public sector organization. Apaza and Chang (2011), moreover, argue that whistleblowing

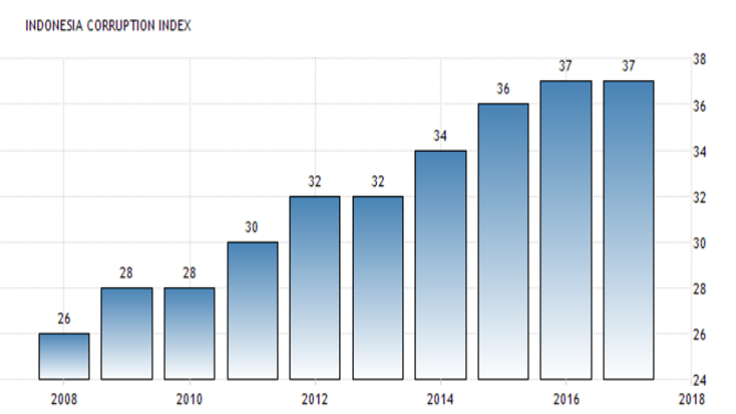

Figure 1. Historical of Indonesia's Corruption Index 1995-2018 Source: Trading Economics (2018); Transparency International (2017)

is an essential means in improving government's transparency and accountability.

The Implementation of Whistleblowing System in the Supreme Audit Board of the Republic of Indonesia or Badan Pemeriksa Keuangan Republik Indonesia (BPK)

Corruption in the public sector in Indonesia is perceived as high. Transparency International (2017) reported that Indonesia's Corruption Perception Index 2017 was scored 37 points out of 100 , on a scale of o (highly corrupt) to 100 (very clean) as stated in figure 1.

Therefore, in Indonesia, there is a regulation regarding the implementation of a whistleblowing system in the public sector, which is Instruksi Presiden Republik Indonesia Nomor 2 Tahun 2014. The law urges governmental institutions in Indonesia to set up a whistleblowing system. However, it does not precisely regulate the elements which should exist in setting up the whistleblowing mechanism to promote the effectiveness of the scheme, such as the tipsters' reward and protection.

One of the governmental organizations which are mandated to implement the whistleblowing system based on the Instruksi Presiden Republik Indonesia Nomor 2 Ta- 
hun 2014 is the Supreme Audit Board of the Republic of Indonesia or Badan Pemeriksa Keuangan Republik Indonesia (BPK). BPK is the only supreme audit institution which has a mandate to audit the use of the state finance in Indonesia independently (Article 1 of Law Number 15 Year 2006). BPK's auditors, therefore, should uphold their independence, integrity and professionalism in conducting an audit to deliver high-quality audit reports (Code of Ethics in BPK, 2016).

After conducting financial report audits, BPK should issue an opinion regarding the auditees' financial statement. The opinion which clarifies that the auditees present a true and fair financial statement, in all material respects, is an unqualified opinion. This opinion is considered an achievement by the governmental institutions in Indonesia. Consequently, governmental departments try their best to produce an adequate financial statement accountably and transparently to gain the unqualified opinion from BPK. The demand for the unqualified opinion creates a gap which could trigger illegal conducts performed both by the auditees and the auditors. The possible fraud could take place, such as bribery from the auditees to the auditors, to urge BPK in issuing an unqualified opinion for the auditees.

Due to the inherent characteristic of audit engagement between auditors and auditees as well as possible fraud which could occur, in term of cost, the potential consequences of the wrongdoing could be the damage of BPK's reputation and the loss of public trust to BPK. Consequently, BPK should implement an effective whistleblowing system to detect any fraudulent activities from the beginning. Since an early fraud detection is believed would lessen tremendous loss in the future which could be suffered by an organization (Pittroff, 2014).

BPK has implemented a whistleblowing sys- tem since 2011 through the Decree of the Secretariat General of BPK Number 507/K/ X-XIII.2/12/2011 about Whistleblowing System in BPK (Keputusan Sekretaris Jenderal Nomor 507/K/X-XIII.2/12/2011). The regulation stated that every employee in BPK is obliged to report any red flags that they know or aware to the addressee which are the Inspektorat Utama BPK, the Human Resources Department and the Direktorat Utama Binbangkum or abbreviated as Satuan Tugas Kepatuhan Internal (Satgas). BPK also provides some channels that can be used by the tipsters to convey the information to the addressee. Besides, the rule ensures that the whistleblowers would be protected, given appreciation as well as informed any action or follow up taken by the addressee.

Therefore, the purpose of this study is to identify some factors which drive employees' intention to whistleblow their tips as well as rank the elements to which are the most favourable to the least important based on the point of view of BPK's officials. The authors, then, will elaborate each element in detail. The authors believe that some factors should be more reinforced than the others to trigger employee's intention in utilising the whistleblowing system. By having knowledge about that, BPK could review and redesign the whistleblowing system which has been implemented since 2011. Thus, the function of whistleblowing mechanism in BPK would be useful in detecting fraud earlier.

\section{LITERATURE REVIEW}

\section{The Damage of Fraud}

Nowadays, fraud is not a novel concept in business. Society comprehends that it is an intentional action taken by one individual to deceive, cheat and get an advantage of another (Albrecht et al., 2014). The scholars 
argue that once fraud happens, it could reduce a company's income on a dollar-fordollar basis. It means that the company's net income will decrease by $\$ 1$ for every $\$ 1$ of fraud. The global financial crisis which happened in late 1999, such as the Enron scandal, became a notorious example of fraud.

Eradicating fraud is a paramount challenge for most companies (Lowe et al., 2015). Fraud is likely to occur because anybody could conduct a fraudulent activity, as long as she or he has an opportunity, pressure and rationalisation (Albrecht et al., 2014). The scholars also emphasise that there is no such thing as a little fraud. When fraud is detected, it is essential to respond to it seriously because if the wrongdoers are allowed to continue, they could become braver and cause greater financial damage (ACFE, 2016; Lewis \& Trygstad, 2009). Thus, an early mechanism for fraud detection is a fundamental element for an organization. However, the increasing number of fraud cases is undeniable. In the private sector, for instance, the percentage of individual frauds, as well as collusive frauds, rose by $82 \%$ and $71 \%$ respectively during 2012 (KPMG, 2012). Besides, the ACFE (2016) explains that most firms might lose approximately $5 \%$ of their annual revenue because of fraud. Moreover, the ACFE's survey which was conducted from January 2014 to October 2015, revealed that from 2,410 fraud cases, the total loss exceeded $\$ 6.3$ billion. Indonesia Corruption Watch (ICW), furthermore, states that public sector organizations also suffer severe damage of fraud. ICW (2017) declares that the number of fraud cases increased by $20 \%$ from 2016 to 2017. Additionally, the amount of state loss rose by $353 \%$ from 2016 (Rp1,450 trillion) to 2017 (Rp6,562 trillion).

Pittroff (2014) also discovers that most organizations implement a whistleblowing sys- tem to comply with the law and to prevent of reputational damage although they are not convinced that it is a valuable resource of tips and complaints. From these facts, it could be concluded that the implementation of the current whistleblowing system may not be as effective as expected.

\section{Whistleblowing System: Its Challenges and Key Elements}

An early fraud detection scheme should be carried out not only by top management but also by all the co-workers since they are in the best position to detect fraud and to provide tips and complaints (Apaza \& Chang, 2011; Albrecht et al., 2014; Dasgupta \& Kesharwani, 2010; Lewis \& Trygstad, 2009; Lowe et al., 2015). Lowe et al. (2015), moreover, assert that lower-level organizational members are often the individuals who could detect a fraudulent act in the first place. Thus, both private and public sector organizations should implement a whistleblowing system to accommodate tips and complaints from employees and third parties.

Dasgupta and Kesharwani (2010) as well as Near and Miceli (1985, p.4, as cited in Pittroff, 2014) define that a whistleblowing as a disclosure given by members of an organization, both current and former employees, about some suspected red flags of fraudulent activities to an addressee that could follow up the information and stop the illegal practices. While Apaza and Chang (2011) as well as Lee and Fargher (2013) argue that an effective whistleblowing system is a mechanism that could cause an organization to investigate the tips received, trigger an institution to strengthen its internal control system, stop the wrongdoing in a reasonable time frame as well as minimize the loss caused by fraud. It is believed that a whistleblowing system could be an initial and the most common fraud detection scheme in some regions, such as United States, Canada, 
Asia-Pacific, Latin America and the Caribbean as well as Europe (ACFE, 2016).

However, many institutions may confront distrust from the employees to engage in a whistleblowing system (Gao et al., 2014). Furthermore, Alleyne et al. (2017) claim that whether employees would use a whistleblowing mechanism depends on their personal decisions about the cost of reporting. Yeoh (2014) also believes that the personal, social and financial cost heavily related to some consequences of disclosing the complaints. Fear of retaliation, as well as a sanction from management and co-workers, could hold someone's intention to blow the whistle (Albrecht et al., 2014; Alleyne et al., 2017). Besides, a hostile environment in an organization, where there is no support from the top management and that a tipster is perceived to be disloyal, would create silence and pressure among the staff to reveal any suspected misconducts (Alleyne et al., 2017; Yeoh, 2014).

Albrecht et al. (2014), moreover, highlight that there are four possible problems which should be addressed when a company applies a whistleblowing system. First, fraud is liquid and abstract (KPMG, 2012). It means that no one could detect that fraud is happening without future investigations. Thus, it might be impossible for a worker to ensure that fraud is occurring in the company. Second, informants are likely to hesitate to come forward since they are afraid of the negative impacts or reprisals that they may encounter as a whistleblower. The employees, thirdly, sometimes are intimidated by the fraudsters, especially if the wrongdoers are managers who have a higher position than them. Lastly, it is challenging to distinguish the motivation of the tipsters. They could report the fraud symptoms honestly and fairly on behalf of the companies' interests. Nevertheless, they may have hidden intentions such as revenge or envy of their colleagues. In addition, Pittroff (2014) assumes that the information given could jeopardise the companies' reputation if it reaches outside the firms.

Consequently, it is prominent to set up a whistleblowing system which is equipped with adequate elements that could trigger employees' intention as well as gain their trust to blow the whistle. Drawing from previous research, several factors are contributing to an effective whistleblowing system, namely:

1. Power to influence the participants

Pittroff (2014) suggests that the effectiveness of a whistleblowing system, which is to discontinue an illegal activity, may rely on a power relation between tipsters and an addressee. The tipsters are employees of an organization who are likely to blow the whistle, whereas an addressee is a person or an institution who receives complaints given by the whistleblowers as well as clarifies the misconducts. The scholar states that an addressee should be perceived as a credible and trustworthy party to gain reliance from employees on using the system. Primarily, if the tipsters are lowlevel employees who have no power resource, they would depend on an addressee that has enough authority to be able to reinforce justice as well as penalise the wrongdoers.

Apaza and Chang (2011), Gao et al. (2014) as well as Yeoh (2014), moreover, explain that an addressee could be an internal or external party in an organization. The scholars argue that low tier staff would prefer an external whistleblowing system since it is likely to have a stronger procedural safeguard. On the other hand, upper-level managers would choose internal reporting channel since they 
concern about the damage of company's reputation because of the adverse publicity. Yeoh (2014), besides, finds that most whistleblowers would disclose some red flags to their supervisor, but they would go external if the supervisors fail to address the tips adequately. In this study, however, the authors will not differentiate the internal and external addressee since BPK has an internal addressee that is the Satgas (Decree of the Secretariat General of BPK Number 507/K/X-XIII.2/12/ 2011). Also, as a governmental institution in Indonesia, the authors expect that it is unlikely BPK would have an external administered whistleblowing system.

\section{Power of the suspected wrongdoers}

It is believed that staff may hesitate to report any fraudulent activities when they are aware that they are the only person aside from the fraudster who know that the illegal conduct is happening in an organization (Robinson et al., 2012). The statement is supported by Pittroff (2014) who argues that some suspected fraudsters who are in the high level of management could threaten the tipsters not to disclose their knowledge about the red flags.

Moreover, fear of reprisal would lessen employees' intention to uncover any illegal conducts (Robinson et al., 2012). Retaliation could take a different form of harmful activities against the whistleblowers. In our setting, retaliation could take place when an employee understands that his or her supervisor involves in fraudulent activity; then, the supervisor knows the individual's awareness. In such a situation, the supervisor possesses a power to negatively revenge the staff such as giving a poor performance, making the staff work overtime or intimidating them. In the public sector organizations, one possible retaliation that may be encountered by the whistleblowers, who are perceived as disloyal, is they could be transferred to unfavourable provinces where are located far away from the employees' home base.

\section{Anonymity and confidentiality}

Albrecht et al. (2014) explain that anonymity is when a whistleblowing mechanism conceals tipsters' identity. It means that the whistleblowers do not oblige to inform their identity to the addressee. The anonymous reporting, then, would lessen the possible retaliation such as sanctions from managers or verbal threats from other coworkers (Alleyne et al., 2017; Lee \& Fargher, 2013). The authors also state that anonymity would create an effective whistleblowing mechanism since it increases the disclosure from the employees via the whistleblowing system.

However, many organizations may be unwilling to implement the anonymous reporting system because it could hinder the future investigation. In this regard, the addressee is unable to obtain further information from the whistleblowers, and the credibility of the complaint is lower if the tipsters remain anonymous. The addressee, consequently, would encounter difficulties to terminate the misconduct since the lack of evidence and limited information gained from the tipsters.

Therefore, the whistleblowing systems may favour confidentiality, whereby the addressee knows the identity of the whistleblower but does not reveal the information publicly (Pittroff, 2014). Nevertheless, this mechanism could encounter employees' hesitancy due to possible retaliation or distrust the addressee (Lee \& Fargher, 2013). These issues could indirectly cause the whistleblowing system to fail. 
Consequently, the confidential-reporting mechanism must be supported by a highly credible and trusted addressee to increase employees' willingness to blow the whistle.

\section{Incentives or rewards}

Firms could encourage their employees to disclose any unlawful activities that they know by offering them some incentives or rewards (Alleyne et al., 2017; Dasgupta \& Kesharwani, 2010; Rose et al., 2018). The scholars also contend that incentives could increase the perceived benefits as well as reduce financial and emotional costs involved in a whistleblowing activity. Moreover, Alleyne et al. (2017) state that incentives could drive the whistleblowers to reveal the tips internally rather than externally.

Nevertheless, Dasgupta and Kesharwani (2010) as well as Yeoh (2014) highlight that some ethicists may criticise the reward system. They believe that the introduction of rewards will not affect someone's intention to blow the whistle. The moral value and altruistic concern would motivate the employees to inform any illegal conducts regardless of any incentives involved. Even lawyers, who have an obligation of confidentiality to clients' interests, have a role as law enforcers and oblige to disclose any clients' wrongdoing on behalf of justice (Parker et al., 2017).

Yeoh (2014), additionally, claims that a suitable amount of financial rewards or an appropriate time to give the incentives to the whistleblowers is another problem. The reward mechanism may not work when the financial settlement is too low or too late given to the tipsters since they may lose their job and find difficulties to find another one because of the employers' reprisal.

\section{Tipsters' protection}

Fear of retaliation has an enormous influence on the effectiveness of the whistleblowing system (Apaza \& Chang, 2011). The authors point out that most tipsters would not come forward since they are afraid of retaliation; thus, the organizations should provide a whistleblower protection law. Without any strong regulation, the tipsters could experience severe consequences even the whistleblowing system effectively solves the damage of fraud.

Moreover, Lewis and Trygstad (2009), as well as Parker et al. (2017) insist that disclosing any illegal conducts is a form of democratic right owned by a member of an organization. Hence, the freedom to speak should be protected legally under a rigid regulation. On the other hand, Pittroff (2014) analyses that statutory regulation to protect whistleblowers may not necessarily lead to an effective whistleblowing system if the management is not convinced of the benefits of the whistleblowing mechanism. Consequently, without any support from the management, the weak law enforcement would not safeguard the whistleblowers from reprisal. In this regard, incentives regulation as explained before could be a better solution to increase employees' awareness of utilising a whistleblowing system.

\section{Management's support}

Alleyne et al. (2017) find that perceived organizational support could positively influence the employees' whistleblowing intentions. The authors believe that upper -level management should create an atmosphere or a culture where ethical 
behaviour is the responsibility of every member of the organization. The decision to inform any illegal conduct via the whistleblowing system, then, could be perceived as an acceptable and ethical practice without any different perception or moral ambiguity.

Besides, Lee and Fargher (2013) reiterate that the ethical environment built by management would positively be related to the extent of whistleblowing disclosure. The scholars, moreover, said that supportive management could encourage anonymous reporting since it simplifies open communication. Also, Kastiel (2015) stresses the importance of "tone at the top" which means managers could be role models who set a culture of corporate governance by encouraging the use of the whistleblowing hotline without hesitation.

\section{Accessibility}

An effective whistleblowing system should provide easy access for potential whistleblowers. It means that the accessibility of the whistleblowing system should be available to the employees and they should be made aware of how to use the system (Kastiel, 2015). The scholar believes that when access to whistleblowing is restricted, it would be harder for the officers to report potential wrongdoing. Besides, the system could be run through a hotline service or secure web access which is supported by sufficient technology and direct reporting.

Furthermore, Lee and Fargher (2013) argue that secure and trusted hotline services could increase the credibility of a whistleblowing system. The implementation of highly used of technology in the reporting channel may be considered expensive for an institution. However, it also signals management's commitment to have an effective whistleblowing mechanism.

8. Training of ethical programs

Robinson et al. (2012) argue that organizations should facilitate the training of ethical programs for all of their employees. The training could strengthen the workers' awareness of the importance to participate in reporting fraud actively. The scholars assert that the training programs could help the staff to understand the potentially severe detriment of financial statement fraud. In this regard, by strengthening employees' moral and ethical value, they would be aware that they should report any fraudulent activities regardless of the wrongdoers' position in the organization.

Additionally, Alleyne et al. (2017) argue that the training course could solve the ethical dilemma and reinforce moral value among employees. By enhancing the ethical value and dignity, every member of an organization would disclose any fraudulent activities since it becomes everyone's responsibility to safeguard the organization's assets as well as reputation.

\section{Management's responsiveness}

How management or addressee responses to the tips and complaints given by the whistleblowers is a significant factor that could influence an employee's intention to blow the whistle (Alleyne et al., 2017). Management's response would also determine the perceived acceptable ethical behaviour in a company. If the management does not appropriately follow up any tips given by the tipsters; then, the other organization's members would neglect their responsibility to report any misconducts since it may be useless. 
Moreover, the actions taken by an addressee is an essential determinant in whistleblowing effectiveness since it informs that appropriate action will be made to address the unethical issue and offers reassurance to the whistleblowers that they will be protected from retaliation (Miceli \& Near, 1992 as cited in Lowe et al., 2015). Robinson et al. (2012) also believe that an adequate response from management, such as giving severe penalties to the wrongdoers and protecting the tipsters from retaliation, would provide a warning to fraudsters that the companies will not tolerate any unlawful actions and will forbid future wrongdoers from committing fraud.

\section{RESEARCH METHODS}

The authors develop a questionnaire to assess the perception of BPK's employees on which of the factors that are significant in convincing them to report any red flags through a whistleblowing mechanism in $\mathrm{BPK}$. The questionnaire consists of close-

Table 1. Key Elements of a Whistleblowing System (Research Variables)

\begin{tabular}{|c|c|c|c|}
\hline Variables & Question Type & Indicators & Scale \\
\hline Power position of whistleblowers & Close-ended question & & Likert \\
\hline \multirow[b]{2}{*}{ Power position of fraudsters } & Close-ended question & & Likert \\
\hline & Open-ended question & $\begin{array}{l}\text { - Anonymity } \\
\text { - Confidentiality } \\
\text { - Others (short answer) }\end{array}$ & \\
\hline Power position of addressee & Close-ended question & & Likert \\
\hline \multirow{2}{*}{$\begin{array}{l}\text { Information of the whistleblowers' } \\
\text { identity }\end{array}$} & Close-ended question & & Likert \\
\hline & Open-ended question & $\begin{array}{l}\text { - Anonymity } \\
\text { - Confidentiality }\end{array}$ & \\
\hline \multirow[b]{2}{*}{ Incentives/rewards } & Close-ended question & & Likert \\
\hline & Open-ended question & $\begin{array}{l}\text { - Financial reward } \\
\text { - Acknowledgement } \\
\text { - Additional leave/free holiday } \\
\text { - Others (short answer) }\end{array}$ & \\
\hline
\end{tabular}

\begin{tabular}{lll}
\hline Whistleblowers' protection & Close-ended question & \multicolumn{2}{l}{ Likert } \\
\hline \multirow{2}{*}{ Management's support } & \multicolumn{2}{l}{ Close-ended question } \\
\cline { 2 - 3 } Open-ended question & Short answer \\
\hline Accessibility & Close-ended question & Likert Hotline \\
\cline { 2 - 3 } & Open-ended question & - Information box (paper based) \\
& & - Others (short answer) \\
\hline
\end{tabular}

\begin{tabular}{lll}
\hline \multirow{2}{*}{ Ethical training program } & \multicolumn{2}{c}{ Close-ended question } \\
\cline { 2 - 2 } & Open-ended question & - Twice a year \\
& & - More than twice a year \\
\hline Management's response & Close-ended question & Likert \\
\hline
\end{tabular}

Source: Processed from various sources 
ended as well as open-ended questions. The close-ended questions include ten items, while short-answer questions comprised of six points. Likert scale analysis, moreover, is used to measure the answers from the respondents for the ten close-ended questions, by categories:

1.Very unlikely to influence/very poor

2.Unlikely to influence/poor

3.Neutral/average

4.Influencing/good

5.Very influencing/very good

The inspected variables are elaborated in table 1.

For the data analysis in this study, the authors use descriptive statistical analysis to rank the most crucial element to the least favourable factor that could trigger BPK employees' intention to utilise the whistleblowing system. After that, the short-answer questions are analysed and grouped based on the most answers given by the respondents. Data processing produces tabulation containing the elements of the whistleblowing system, number of respondents, percentage and additional information which are gained from the open-ended questions.

\section{Population and Sample}

The population of this study is all of BPK's employees. The authors are not differentiating the role and responsibility as well as the managerial position of respondents since the authors believe that every member of BPK could be a potential whistleblower. Therefore, simple random sampling is used since every individual in the population would gain the same probability being chosen as a sample. In the questionnaire, the

Table 2. Respondents' Background and Their Role in BPK

\begin{tabular}{|c|c|}
\hline Variables & Indicators \\
\hline \multirow[t]{2}{*}{ Gender } & - Male \\
\hline & - Female \\
\hline \multirow[t]{4}{*}{ Age } & - 20-30 years old \\
\hline & - 31-40 years old \\
\hline & - 41-50 years old \\
\hline & - More than 50 years old \\
\hline \multirow[t]{2}{*}{ Role in BPK } & - Auditor \\
\hline & - Administration officer \\
\hline \multirow[t]{4}{*}{ Managerial position in BPK } & - Team member (Administrasi Umum, Anggota Tim Yunior, Anggota Tim Senior) \\
\hline & - Team leader (Ketua Tim Yunior, Ketua Tim Senior, Pejabat Eselon IV) \\
\hline & - Controller (Pengendali Teknis, Pejabat Eselon III) \\
\hline & - Others \\
\hline \multirow[t]{5}{*}{ Working tenure in BPK } & $-0-5$ years \\
\hline & $-5-10$ years \\
\hline & - 11-15 years \\
\hline & - 16-20 years \\
\hline & - More than 20 years \\
\hline \multirow[t]{4}{*}{ Educational background } & - Diploma (DI/DIII) \\
\hline & - Undergraduate (S1/D4) \\
\hline & - Postgraduate (S2) \\
\hline & - Doctorate (S3) \\
\hline
\end{tabular}

Source: Authors 
authors also developed several questions regarding respondents' identity to indicate the various background as well as different roles of the respondents in BPK, as seen in table 2.

Table 2 shows that the authors try to identify respondents' identity by taking into account their gender, age, working tenure, educational background as well as different roles and responsibilities that they have in BPK. By having various respondents with different background and managerial position in BPK, the result of analysis could be generalised and applied toward upper-level managers as well as low-level employees.

\section{RESULT AND DISCUSSION}

From July to August 2018, the authors have distributed 775 questionnaires to BPK's employees. Table 3 indicates that the 775 questionnaires have been distributed to BPK's employees. During the two months of collecting period, the authors received $10 \%$ reply from the respondents which are 79 answers. The respondents' details, as seen in table 4.

From table 4, it can be concluded that female and male respondents share proportions which are $48 \%$ and $52 \%$, respectively. Then, most of the respondents are auditors who are

Table 3. Distribution of Questionnaire

\begin{tabular}{cc}
\hline BPK's Office & $\begin{array}{c}\text { Number of } \\
\text { Questionnaire }\end{array}$ \\
\hline Head office in Jakarta & 382 \\
\hline BPK's Representative Office & 393 \\
\hline Total & 775 \\
\hline
\end{tabular}

Source: Author's data processing and analysis

among 30 to 40 years old and have been working in BPK for about 5 to 10 years. They are likely to be team members or lower level

employees who may have the best position in detecting any illegal misconducts earlier (Albrecht et al., 2014; Apaza \& Chang, 2011; Dasgupta \& Kesharwani, 2010; Lewis \& Trygstad, 2009; Lowe et al., 2015). Whereas, senior officers who have 11 to more than 20 years of working experience in BPK also participated in this study. They may have a role as team leaders in audit teams or high-level managers who could significantly support and become champions for the implementation of the whistleblowing mechanism in BPK.

Table 4. Information of Respondents' Background and Roles in BPK

\begin{tabular}{|c|c|c|}
\hline Variables & $\begin{array}{c}\text { Number of } \\
\text { Question- } \\
\text { naire }\end{array}$ & $\%$ \\
\hline \multicolumn{3}{|l|}{ Gender } \\
\hline Female & 38 & $48 \%$ \\
\hline Male & 41 & $52 \%$ \\
\hline \multicolumn{3}{|l|}{ Age } \\
\hline $20-30$ years old & 10 & $13 \%$ \\
\hline $31-40$ years old & 57 & $72 \%$ \\
\hline $41-50$ years old & 12 & $15 \%$ \\
\hline \multicolumn{3}{|l|}{ Role in BPK } \\
\hline Auditor & 62 & $79 \%$ \\
\hline Administration Officer & 17 & $22 \%$ \\
\hline \multicolumn{3}{|l|}{ Managerial Position in BPK } \\
\hline Team member & 59 & $75 \%$ \\
\hline Team leader & 17 & $22 \%$ \\
\hline Controller & 1 & $1 \%$ \\
\hline Others & 2 & $3 \%$ \\
\hline \multicolumn{3}{|l|}{ Working Tenure } \\
\hline $0-5$ years & 7 & $9 \%$ \\
\hline $5-10$ years & 43 & $54 \%$ \\
\hline $11-15$ years & 21 & $27 \%$ \\
\hline $16-20$ years & 3 & $4 \%$ \\
\hline More than 20 years & 5 & $6 \%$ \\
\hline \multicolumn{3}{|l|}{ Educational Background } \\
\hline S1/D4 & 52 & $66 \%$ \\
\hline S2 & 27 & $34 \%$ \\
\hline Total & 79 & $100 \%$ \\
\hline
\end{tabular}


The authors, then, investigate the awareness of the respondents that BPK has implemented a whistleblowing system since 2011. The result shows that $66 \%$ of them understand that a whistleblowing mechanism exists in BPK. The last 34\%, unfortunately, do not

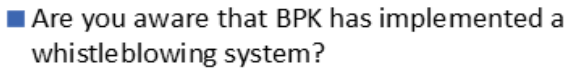
whistleblowing system?

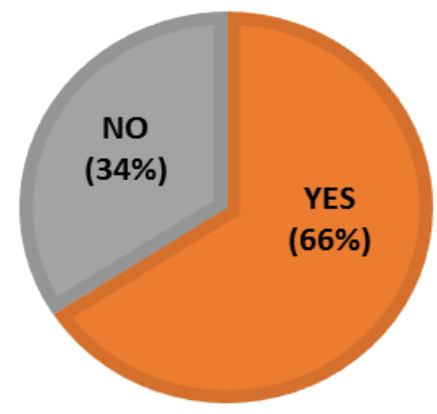

Figure 2. Employees' awareness of the whistleblowing system in BPK

Source: Author's data processing and analysis

comprehend that BPK has implemented a whistleblowing system for about seven years as shown in figure 2. The authors, moreover, find that none of the respondents has utilised a whistleblowing mechanism in BPK, as shown in figure 3 .

Furthermore, the result of the descriptive statistical analysis, as well as answers to the open-ended questions, are elaborated in table 5 . Based on the table 5 , it can be summarised that BPK's employees consider the whistleblowers' protection as the most critical component which should be strengthened in a whistleblowing mechanism (mean 4.684). By having a rigid whistleblowers' protection regulation, it would lessen their hesitation in disclosing any unlawful activity to the addressee. Consequently, fear of reprisal from the supervisor and possible bully as disloyal from other co-workers are the biggest challenges that BPK should overcome to run an effective whistleblowing system.

Management's support is the second most crucial element in a whistleblowing mechanism in BPK (mean 4.582). In this regard, the upper-level managers should set a tone at the top that disclosing any fraudulent activities to the addressee is acceptable and ethical behaviour. Additionally, many respondents demand moral support from their supervisor as well as the transparent process

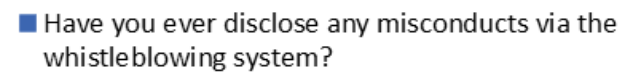
whistleblowing system?

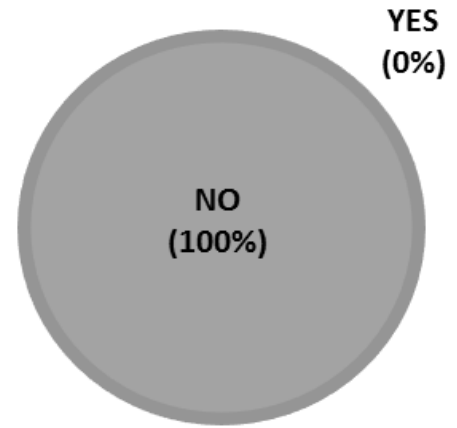

Figure 3. The utilisation of the whistleblowing system in BPK

Source: Author's data processing and analysis

in every step taken to terminate the fraudulent activities reported by them.

Moreover, assertive respond and follow up toward the tips given by the whistleblowers is the third factor which could influence BPK's employees to disclose any wrongdoing (mean 4.455). Severe punishment to the fraudsters would create a deterrent effect, signalling that BPK is seriously combating any wrongful conducts among employees and preventing any fraud to reoccur in the future.

Fourth, many respondents prefer anonymity (58\%) over confidentiality (39\%) when it relates to the secrecy of the whistleblowers' identity. It means that BPK's employees choose not to disclose their identity to the addressee. On the one hand, anonymity could increase the disclosure through an effective whistleblowing system (Lee \& Fargher, 2013). On the other hand, Pittroff (2014) argues that anonymity could reduce the credibility of the complaints as well as hinder future investigation conducted by the addressee. Nevertheless, the limitations 
Table 5. The Crucial Elements of a Whistleblowing Mechanism based on the Perspective of BPK's Employees

\begin{tabular}{|c|c|c|c|c|c|}
\hline Rank & Elements of Whistleblowing System & Mean & $\begin{array}{l}\text { Additional } \\
\text { Information }\end{array}$ & $\begin{array}{l}\text { Number of } \\
\text { Response }\end{array}$ & $\%$ \\
\hline 1 & Whistleblowers' protection & 4.684 & & & \\
\hline 2 & Management's support & 4.582 & & & \\
\hline 3 & Management's response/follow up & 4.456 & & & \\
\hline \multirow{3}{*}{4} & \multirow{3}{*}{$\begin{array}{l}\text { Information of the whistleblower's iden- } \\
\text { tity }\end{array}$} & \multirow{3}{*}{4.418} & Anonymity & 46 & $58 \%$ \\
\hline & & & Confidentiality & 31 & $39 \%$ \\
\hline & & & Blank & 2 & $3 \%$ \\
\hline 5 & Power position of addressee & 4.405 & & & \\
\hline \multirow{4}{*}{6} & \multirow{4}{*}{ Ethical training program } & \multirow{4}{*}{4.392} & Once in a year & 47 & $59 \%$ \\
\hline & & & Twice in a year & 19 & $24 \%$ \\
\hline & & & $\begin{array}{l}\text { More than twice in } \\
\text { a year }\end{array}$ & 5 & $6 \%$ \\
\hline & & & Blank & 8 & $10 \%$ \\
\hline \multirow{5}{*}{7} & \multirow{5}{*}{ Accessibility } & \multirow{5}{*}{4.380} & Hotline & 15 & $19 \%$ \\
\hline & & & Website & 42 & $53 \%$ \\
\hline & & & $\begin{array}{l}\text { Information box } \\
\text { (paper based) }\end{array}$ & 13 & $16 \%$ \\
\hline & & & Others & 7 & $9 \%$ \\
\hline & & & Blank & 2 & $3 \%$ \\
\hline \multirow{2}{*}{8} & \multirow{2}{*}{ Power position of fraudsters } & \multirow{2}{*}{4.063} & Anonymity & & \\
\hline & & & Confidentiality & & \\
\hline 9 & Power position of whistleblowers & 3.987 & & & \\
\hline \multirow{5}{*}{10} & \multirow{5}{*}{ Incentives/rewards } & \multirow{5}{*}{3.684} & Financial reward & 15 & $19 \%$ \\
\hline & & & Acknowledgement & 23 & $29 \%$ \\
\hline & & & $\begin{array}{l}\text { Additional leave/ } \\
\text { free holiday }\end{array}$ & 5 & $6 \%$ \\
\hline & & & Others & 9 & $11 \%$ \\
\hline & & & Blank & 27 & $34 \%$ \\
\hline
\end{tabular}

Source: Author's data processing and analysis

caused by an anonymous reporting mechanism could be managed if the whistleblowing system requires adequate evidence given by the tipsters when they disclose any misconducts. The evidence would help the addressee to follow up and inspect the potential fraud optimally.

Power position owned by the addressee, the whistleblowers as well as the potential fraudsters, furthermore, are the fifth (mean 4.405), the eighth (mean 4.063) and the ninth (mean 3.987) essential elements which could be considered by the potential tipsters as factors that could escalate the personal costs when they blow the whistle. As mentioned before, potential tipsters especially who are low-level staff would rely on a credible and trusted addressee to protect them from retaliation of the potential wrongdoers
(Pittroff, 2014).

Sixth, most of BPK's officers believe that ethical training program which is conducted at least once a year is an essential factor in establishing an effective whistleblowing system (mean 4.392). The training programs not only reinforce ethical behaviour and value among the employees but also clarify any moral ambiguity in the organization. A false paradigm about "being a whistleblower means being disloyal to employers" would vanish over the time. Moreover, ethical training would help the staff to comprehend the severe consequences of fraud (Robinson et al., 2012). Regular ethical training programs would also create awareness among the employees in BPK that a whistleblowing mechanism exists as a secure media to disclose and prevent any wrongdoing on behalf of justice 
and altruism.

Many respondents also believe that secure access to the whistleblowing mechanism would increase their intention to whistleblow (mean 4.380). They choose a website, hotline service and information boxes as the means to disclose the tips and complaints, which are $53 \%, 19 \%$ and $16 \%$, respectively. Other respondents also reckon that email and text message could be used to communicate information about illegal activities that they suspect is happening in BPK. As Lee and Fargher (2013) state that a secure hotline channel would increase anonymity and cause deterrent effects toward potential perpetrators. Nevertheless, to run a website as a media of communication between an addressee and potential whistleblowers could be costly for an institution, but it also points out management's commitment and support in establishing an effective whistleblowing system.

The least important factor in influencing BPK's employees to blow the whistle is rewards or incentives (mean 3.684). Accordingly, Dasgupta and Kesharwani (2010) state that awards will not affect someone's intention to disclose any wrongdoing since it is the moral value that motivates the employees to distinguish the right and wrong matter. The result contradicts to Alleyne et al. (2017) who believe that rewards mechanism could increase disclosure via a whistleblowing system.

Nevertheless, if BPK's employees could receive any rewards for their bravery in disclosing any wrongful conducts, they may prefer to obtain acknowledgment or honour from their employers and colleagues (29\%), financial rewards (19\%) and additional leave or vacation (6\%). While, the other $34 \%$ of respondents do not disclose their opinion regarding the preferred rewards, the $11 \%$ of them mention that they would like to be ro- tated to their home-based, gained promotion and being informed of every progress taken by the addressee in following up the fraud case as well as acquired financial bonuses.

\section{CONCLUSION}

To sum up, there are ten elements to be considered when an institution sets a whistleblowing mechanism. Those factors could trigger employees' intention in disclosing any illegal conducts, such as bribery, to the addressee. BPK as one of the governmental institutions which are obliged to set up a whistleblowing system should take into account these elements as well. Nevertheless, one factor may be more important to be strengthened than the others; thus, the authors rank these items based on the perspective of BPK's employees.

The most crucial elements that the management should count is the protection to the potential whistleblowers. Next, the upperlevel management should set a tone at the top by legally, morally and financially supporting the tipsters who blow the whistle publicly. After that, management or the addressee should objectively follow up any tips and complaints given by the whistleblowers. Also, an anonymous reporting mechanism could increase the disclosure through a whistleblowing system. Many respondents, additionally, state that ethical training program could establish an ethical environment as well as strengthen moral value among the staff. Besides, the respondents would examine the power position owned by the addressee, the possible wrongdoers and themselves as potential tipsters as factors that will increase or decline reasonable personal cost to blow the whistle.

Most of BPK's employees, moreover, prefer website and hotline service as a means of 
communication to deliver any information regarding red flags. The methods of communication also increase anonymity and likelihood of an effective whistleblowing system. Lastly, rewards and incentives such as acknowledgement, promotion and bonuses are the least criteria which could trigger a potential whistleblower to come forward in BPK.

Although the result of the descriptive statistical analysis shows that the most crucial component in a whistleblowing system in BPK is the whistleblowers' protection and the least important factor to be considered is the rewards mechanism, these elements complement each other to establish an effective whistleblowing system, as shown in figure 4.

In other words, even the whistleblowers' protection is the most prominent element; but, it could not make a whistleblowing system becomes effective without any support from the management, a credible addressee, se- cure access to the system, regular training of ethical program or an acknowledgement given to the potential tipsters. As described in figure 4 , all of the elements are an integral factor in a whistleblowing mechanism, where the management support as the centre of the system. Meaning that every factor in the whistleblowing system could exist by the support and commitment from the management to gain the benefit from the system. The advantage of a whistleblowing system may not be acquired in a short period, but an effective whistleblowing mechanism is the most effective and universal tool in the fraud detection scheme to prevent tremendous loss such as the damage of BPK's reputation towards the public in the future.

\section{Implication}

Our proposed study would contribute to management in BPK to revisit the whistleblowing mechanism which has been implemented since 2011. Then, BPK's manage-

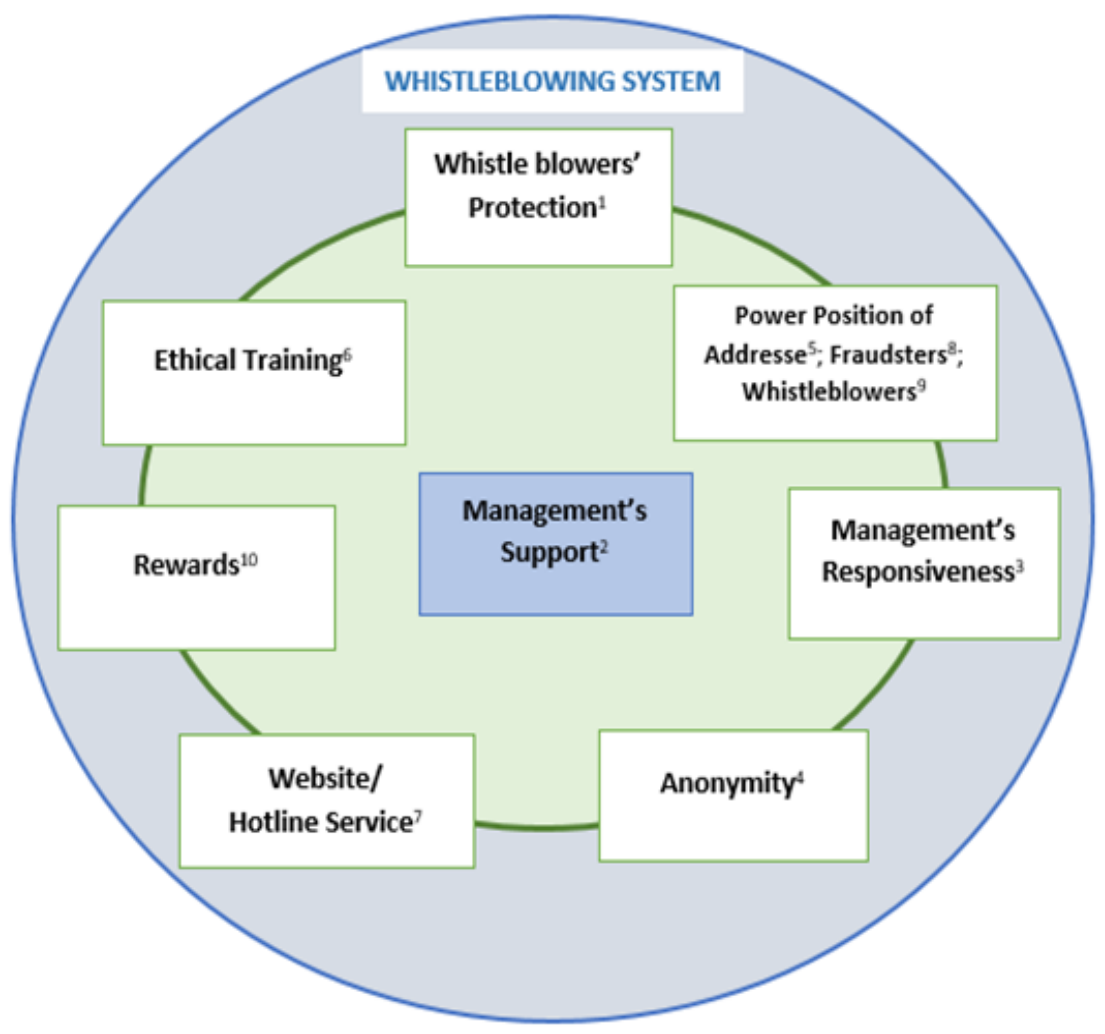

Figure 4. Key Elements in an Effective Whistleblowing System

Source: Authors 
ment could reformulate an effective whistleblowing system in the organization. Arguably, effective whistleblowing should be perceived as a credible and secure system; thus, the employee would disclose any wrongdoing without any hesitation. Since Apaza and Chang (2011), Albrecht et al. (2014), Dasgupta and Kesharwani (2010), Lewis and Trygstad (2009) as well as Lowe et al. (2015) state that it is usually the employees who have the best position in detecting fraud in the first place; hence, it is essential to consider their perception of what factors should be put in place to strengthen the whistleblowing system in BPK.

\section{Limitation}

The limitation of this study is the limited data which has been used and analysed; thus, future research with various data from more respondents and different organizations could give a broader knowledge about the elements which are crucial in setting up an effective whistleblowing system. Furthermore, the study is conducted in BPK; the authors do not ensure if the result could be applied in other governmental institutions or private sectors because of the different characteristics of every organization.

Moreover, the authors do not examine the personal value, moral intensity, cultural background or working tenure of the respondents which may or may not influence their decision to report some red flags via the whistleblowing system. The next study may need to consider those factors through a focus discussion group or a case study setting.

\section{REFERENCES}

ACFE. (2016). Report to the nations on occupational fraud and abuse. Austin, TX:
Association of Certified Fraud Examiners.

Apaza, C. R., \& Chang, Y. (2011). What makes whistleblowing effective. Public Integrity, 13(2), 113-130.

Albrecht, W. S., Albrecht, C. O., Albrecht, C. C., \& Zimbelman, M. F. (2014). Fraud examination ( $5^{\text {thed. }}$.). Cengage Learning United States of America, Boston.

Alleyne, P., Charles-Soverall, W., Broome, T., \& Pierce, A. (2017). Perceptions, predictors and consequences of whistleblowing among accounting employees in Barbados. Meditari Accountancy Research, 25(2), 241-267. Retrieved from https://search.proquest.com/ docview/ 1911202010? accountid $=86413$.

Code of Ethics in BPK Number 3 Year 2016 (Peraturan BPK Nomor 3 Tahun 2016 tentang Kode Etik BPK). Retrieved from https://peraturan.bpk.go.id/ Home/Details/24.

Dasgupta, S., \& Kesharwani, A. (2010). Whistleblowing: a survey of literature. IUP Journal of Corporate Governance, 9(4), 57-70. Retrieved from https://search.proquest.com/doc view/759597922? accountid $=86413$.

Decree of the Secretariat General of the State Audit Board of the Republic of Indonesia Number 507/K/X-XIII.2/ 12/2011 about Whistleblowing in BPK (Keputusan Sekretaris Jenderal Nomor 507/K/X-XIII.2/12/2011 tentang Penanganan pelaporan pelanggaran atau whistleblowing di lingkungan $B P K)$.

Gao, J., Greenberg, R., \& Wong-On-Wing, B. (2014). Whistleblowing intentions of 
lower-level employees: the effect of reporting channel, bystanders, and wrongdoer power status. Journal Business Ethics, 126(1), 85-99. doi: 10.1007/s10551-013-2008-4.

Indonesia Corruption Watch. (2017). The increase of corruption cases in 2017. Retrieved from: https://antikorupsi. org/id/content/2017-jumlah-kasuskorupsi-menanjak?

width $=1000$ \&height $=700$.

Kastiel, K. (2015, October 25). Elements of an effective whistle blower hotline. Retrieved from https://corpgov.law. harvard.edu/2014/10/25/elements-of -an-effective-whistleblower-hotline/.

KPMG. (2012). A survey of fraud, bribery and corruption in Australia and New Zealand 2012. Australia: Author.

Law of The Republic of Indonesia Number 15 Year 2006 about the Supreme Audit Board of the Republic of Indonesia (Undang-Undang Republik Indonesia Nomor 15 Tahun 2006 tentang Badan Pemeriksa Keuangan). Retrieved from http://bandung.bpk. go.id/files/2009/03/UU-15-Tahun2006.pdf.

Lee, G., \& Fargher, N. (2013). Companies' use of whistleblowing to detect fraud: an examination of corporate whistleblowing policies. Journal of Business Ethics, 114(2), 283-295. doi: 10.1007/ s10551-012-1348-9.

Lewis, D., \& Trygstad, S. (2009). Protecting the whistleblowers in Norway and the UK: A case of mix and match? International Journal of Law and Management, 51(6), 374-388. doi: 10.1108/17542430911005918.
Lowe, D. J., Pope, K. R., \& Samuels, J. A. (2015). An examination of financial sub-certification and timing of fraud discovery on employee whistleblowing reporting intentions. Journal of Business Ethics, 131(4), 757-772. doi: 10.1007/s10551 -013-2020-8.

Parker, C., Le Mire, S., \& MacKay, A. (2017). Lawyers, confidentiality and whistleblowing: lessons from the Mccabe tobacco litigation. Melbourne University Law Review, 40 (3), 999-1056. Retrieved from https://search.proquest.com/doc view/1899315590?accountid=86413.

Pittroff, E. (2014). Whistleblowing systems and legitimacy theory: A study of the motivation to implement whistleblowing systems in German organizations. Journal of Business Ethics, 124 (3), 399-412. doi: 10.1007/s10551-013 -1880-2.

Presidential Instruction of the Republic of Indonesia Number 2 Year 2014 about Corruption prevention and eradication (Instruksi Presiden Nomor 2 Tahun 2014 tentang Aksi pencegahan dan pemberantasan korupsi). Retrieved from http://www.itjen. depkes.go.id/public/upload/unit/pusat/ files/Inpres\%20Nomor\%202\% 2otahun\%202014\%20 (2)(1).pdf.

Robinson, S. N., Robertson, J. C., \& Curtis, M. B. (2012). The effect of contextual and wrongdoing attributes on organizational employees' whistleblowing intentions following fraud. Journal of Business Ethics, 106, 213-227. doi: 10.1007/s10551-011-0990-y.

Rose, J. M., Brink, A. G., \& Carolyn, S. N. (2018). The effects of compensation structures and monetary rewards on 
managers' decisions to blow the whistle. Journal of Business Ethics, 150 (3), 853-862. doi: 10.1007/s10551016-3222-7.

Transparency International. (2017). Corruption perceptions index 2017. Retrieved from https:// www.transparency.org/news/feature/ corruption_perceptions_index_2017.

Trading Economics. (2018). Indonesia corruption index 1995-2018. Retrieved from https://tradingeconomics.com/ indonesia/corruption-index.

World Bank. (June, 2017). World Bank list of economies (June 2017). Retrieved from http://iccmoot.com/wpcontent/uploads/2017/o7/WorldBank-List-of-Economies.pdf.

Yeoh, P. (2014). Whistleblowing: Motivations, corporate selfregulation, and the law. International Journal of Law and Management, 56 (6), 459-474. Retrieved from https:// search.proquest.com/docview/ 1650884799 ?accountid $=86413$. 


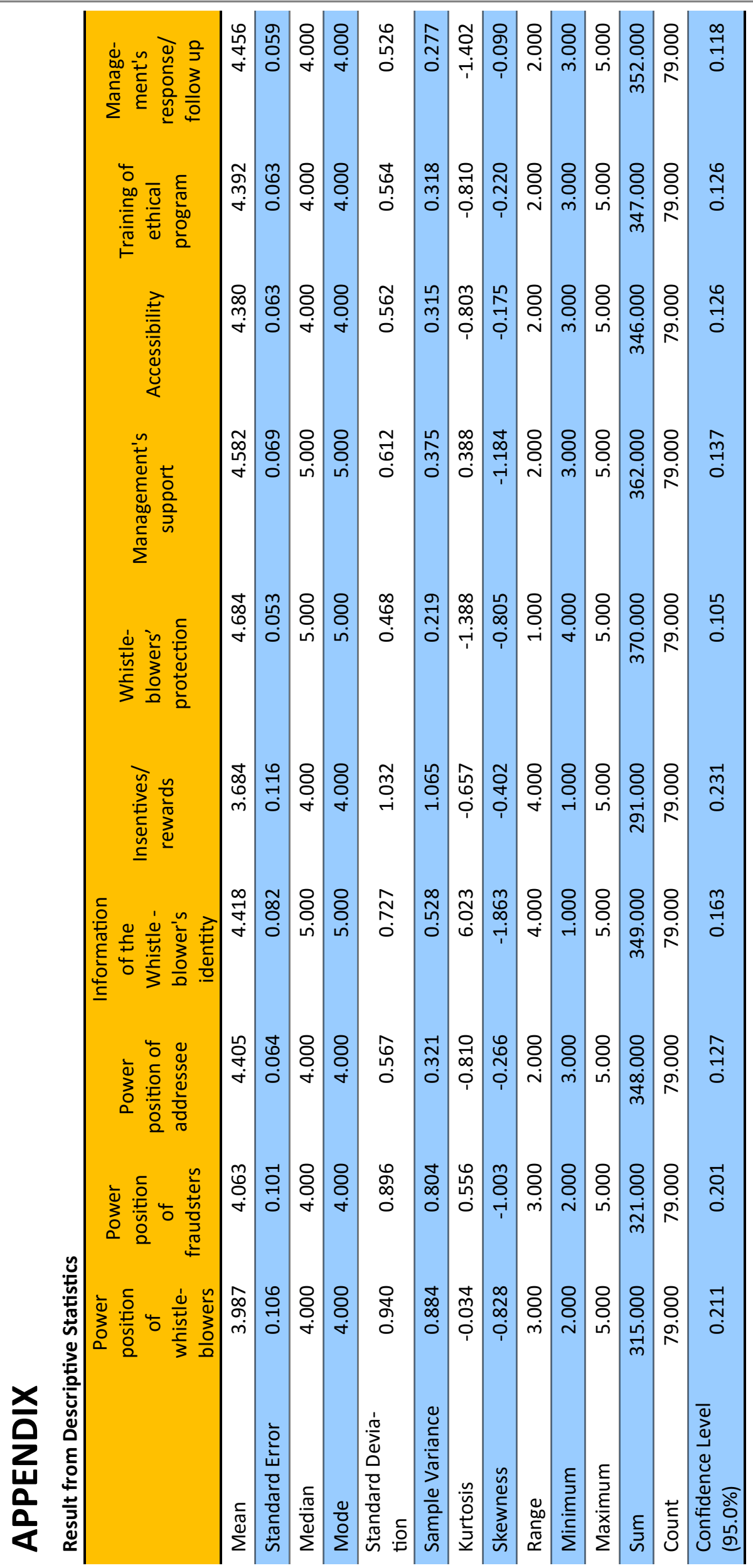

